\title{
EM SO DALAM RITUS TOW POK MBU SUKU ASMAT (Suatu kajian Etnomusikologi)
}

\author{
Mien Yanelia Koupun
}

\begin{abstract}
Asmat is one of the famous and largest tribe in Papua. Beside famous with traditional wood carvings typical, Asmat also well known through traditional rituals performed. One such ritual is Sago Worm festival(Tow Pok Mbu), which also do three important things namely singing, dancing and eating together.This ritual is done because the Asmat has its own views on sago palm as a symbol of a mother who gives the best for their family members.The objective of this ritual is as a form of appreciation, how their lives are built and continue in relationship with God, others and nature.In this ritual, singing music oftifa (kind of music drum of East Indonesia)(Em so) provide its own nuances that delves on admiration for God's creation, gratitude and pleaded secure and mutually reconciled life and sharing. Em so as a means of expression of feelings and their praises to the Divine through Fumeripits (Ancestor) and emphasized the importance of living together as a community.
\end{abstract}

Keywords: Singing music of tifa (Em so), sago worm festival (Tow Pok Mbu), Asmat

\begin{abstract}
Abstrak
Suku Asmat adalah salah satu suku yang terkenal dan terbesar di Papua. Selain terkenal melalui ukiran kayu tradisional yang sangat khas, Asmat juga terkenal melalui berbagai ritual adat yang dilakukan. Salah satunya yaitu Ritual Pesta Ulat Sagu (Tow Pok Mbu) yang didalamnya dilakukan tiga hal penting yaitu menyanyi, menari dan makan bersama.Ritual ini dilakukan karena orang Asmat punya pandangan tersendiri tentang pohon sagu sebagai simbol seorang ibu yang memberi yang terbaik bagi anggota keluarganya.Tujuan dilaksanakannya ritus ini yaitu sebagai bentuk penghayatan, bagaimana kehidupan mereka dibangun dan terus berlangsung dalam hubungannya dengan Tuhan, sesama dan alam. Dalam ritual ini, nyanyian musik tifa(Em so) memberikan nuansa tersendiri yang mengkisahkan tentang kekaguman terhadap ciptaan Tuhan, rasa syukur dan memohon penjagaan serta hidup saling berdamai dan berbagi. Em so sebagai sarana ungkapan perasaan dan puji-pujian mereka kepada Sang Ilahi melalui Fumeripits (Leluhur) serta menegaskan, pentingnya hidup bersama sebagai satu persekutuan.
\end{abstract}

Kata kunci :Musik tifa (Em so), Tradisi Ritual (Tow Pok Mbu), Asmat 


\section{Pendahuluan}

Musik tidak dapat berkembang jika tanpa memiliki asosiasi makna diantara masyarakatnya. Oleh karenanya, musik memiliki hubungan yang mendalam dengan perasaan dan pengalaman masyarakatnya. Tidak mengherankan jika kemudian, Blacking menempatkan suara atau musik sebagai subjek atau entitas yang dapat menjelaskan suatu kebudayaan masyarakat tertentu. ${ }^{1}$ Pada hakekatnya, musik juga memiliki dimensi lain yang dapat memengaruhi orangyang mendengarnya. Menurut Alf Gabrielsson, seorang ahli di bidang psikologi musik, untukmemahami ekspresi emosi dalam musik, kita perlu membedakan antara proses "emotion perception" dan "emotion induction". Maksudnya, seorang pendengar musik dapat saja menangkap ekspresi emosi dari sebuah musik tanpa perlu mengalami emosi itu sendiri. Proses inilah yang dimaksud dengan emotion perception atau persepsi emosi yang terkandung dalam musik. Itu artinya ada nilai “objektif” dari fungsi emosional musik, yangmembuat kita sebagai pendengar dapat mengenali musik yang bernuansa „sedih", „gembira"e, relaxingee, dan sebagainya. Lebih jauh lagi, saat mendengar sebuah musik, kita dapat "mengalamie emosi tertentu. Inilah proses emotion induction, di mana musik membawa kita hanyut dalam emosi tertentu. Seseorang, karenanya, dapat dengan bebas memberikan respon emosi terhadap musik yang didengarnya. Emotion perception dimaksudkan sebagai kerja intelektual (sebatasproses persepsi kognitif) sedangkan emotion induction melibatkan respon emosional (apayang dirasakan saat mendengar musik tertentu) ${ }^{2}$

Bagi masyarakat Papua, musik bukanlah hal yang baru. Musik telah menyatu dengan kehidupan mereka jauh sebelum merka mengenal tulisan. Emosi berupa luapan kegembiraan mereka maupun kesedihan dalam musik yang digunakan. Bukanlah hal baru jika masyarakat Papua sudah terbiasa dengan musik, bahkan musik digunakan dalam hidup sehari-hari tapi juga dalam berbagai ritual adat. Misalnya, musik tifa sebagai salah satu ikon alat musik pendukung budaya. Musik pukul khas Indonesia Timur ini menyerupai gendang dan terbuat dari kayu dengan lubang dibagian tengah. Musik tifa di gunakan sebab tifa sudah diwariskan oleh para leluhur sehingga harus dijaga dan dilestarikan bagi anak cucu. Tifa sebagai alat musik tradisional orang Asmat, dibuat dalam bentuk yang unik karena terbuat dari kayu keras yang dilubangi dan dihiasi dengan berbagai ukiran baik itu di bagian badan tifa tapi juga pada 
tempat pegangannya ${ }^{3}$. Umumnya Lubang tersebut ditutupi kulit rusa namun tidak bagi Masyarakat suku Asmat. Alat musik tifa ini ditutupi dengan kulit biawak yang sudah dikeringkan sebab lingkungan daerah Asmat memungkinkan untuk hidupnya habitat biawak dan tidak untuk binatang Rusa.

Dunia masyarakat suku Asmat merupakan dunia yang unik.Keunikan itu dijiwai dari pengalaman masa lalu yang berbeda dengan pengalaman suku-suku lainnya di Papua yakni tradisi masa lalu mengenai kanibal yang hingga kini, masih menjadi momok menakutkan ketika orang mendengar tentang Asmat. ${ }^{4}$ Benarlah apa yang dikatakan Ernst bahwa setiap organisme adalah mahkluk monadis. Setiap organisme mempunyai pengalamannya sendiri karena itu memiliki dunianya sendiri” ${ }^{\circ}$. Sebagai salah satu suku terbesar dan paling terkenal di antara sekian banyak suku yang ada di Papua, Asmat terus mengalami perubahan dalam berbagai sisi sejak dimekarkan tahun 2004 dari Kabupaten Merauke sebagai Kabupaten induk. Wilayah yang ditinggali juga sangat unik. Dataran coklat lembek yang tertutup oleh jaring laba-laba sungai. Tidak ada pilihan lain, daerah yang berawa-rawa menyebabkan masyarakat harus berjuang melangsungkan aktivitas hidup diatas papan.

Salah satu hal yang membuat suku Asmat dikenal adalah hasil ukiran kayu tradisional yang sangat khas. Selain ukiran kayu yang sudah mendunia, Asmat terkenal juga melalui berbagai upacara (ritual) adat. Misalnya, ritual Tow Pok Mbu (Pesta Ulat Sagu). Ritus ini adalah salah satu ritual adat yang hidup dan menghidupkan mereka dalam merefleksikan eksistensi dalam komunitasnya. Dalam ritual ini, musik tifa mempunyai peranan tersendiri yaitu sebagai pengiring nyanyian (So) dan juga pengiring tarian (Ndi). Tifa akan di tabuh sedemikian rupa untuk mengiringi nyanyian dan tarian dan itu menjadi gaya khas sesuai identitas cultur suku Asmat yang nampak dalam ritus Tow Pok Mbu.

Menurut Thomas Bapchi, ritus Tow Pok 'Mbu dilakukan karena orang Asmat memandang pohon sagu berbeda dengan pohon-pohon lain disekitar mereka. Pohon Sagu diibaratkan sebagai seorang perempuan. Suatu kehidupan di percaya oleh orang Asmat, keluar dari Pohon sagu sebagaimana kehidupan keluar dari rahim seorang perempuan sehingga semua yang berhubungan dengan pohon 
sagu baik itu akar, batang, bagian dalam batang sagu (sagu = ambas $)$, bagian dalam batang sagu yang dibiarkan membusuk (ulat sagu = tow Ambas) dan daun sagu (Ambas Opom) semuanya punya nilai tersendiri yang tidak dapat dilepaspisahkan dalam kehidupan mereka ${ }^{6}$. Hal ini menunjukan bahwa Pohon sagu memiliki arti tersendiri.

Selain sebagai makanan pokok masyarakat, pohon sagu dimaknai sebagai pohon pemberi hidup. Pohon sagu adalah mama yang melahirkan mereka. Mereka tidak bisa hidup tanpa pohon sagu. Hal inilah yang digambarkan dalam ritus Tow Pok 'Mbu. Melalui ritus ini, perjalanan hidup sebagai suatu komunitas dihayati dalam hubungannya dengan Tuhan yang di sembah, sesama dan alam.Dalam Ritus ini, nyanyian musik tifa (em so) memberikan nuansa tersendiri yang berkaitan dengan kedalaman makna sebagai bentuk penghayatan, bagaimana kehidupan dibangun dan terus berlangsung dalam hubungannya dengan Tuhan, sesama dan alam. Daniel Dampits mengatakan, Em so dalam ritus Tow Pok Mbu suku Asmat mengisahkan tentang kekaguman terhadap ciptaan Tuhan, rasa syukur kepada Sang Bapa dan memohon penjagaannya serta hidup saling berdamai dan berbagi ${ }^{7}$. Em so sebagai sarana ungkapan perasaan dan puji-pujian dan cinta meraka kepada Sang Ilahi melalui Fumeripits (Leluhur) ${ }^{8}$ serta menegaskan, pentingnya hidup bersama sebagai satu persekutuan.Pengakuan yang mendasari ritus ini adalah pengakuan kepada Tuhan Sang pencipta sagu "mama". Tuhan dipahami sebagai Sumber cinta, yang menganugerahkan pohon sagu sebagai kehidupan bagi mereka. Pengakuanini adalah pengakuan yang "dihidupi oleh komunitas suku Asmt. "Em So adalah kehadiran cinta" menggemakan kesederhanaan sekaligus keagungan penghayatan komunitas suku Asmat terhadap Tuhan. Tuhanyang mencinta menunjukkan keindahan relasi antara Tuhan dan manusia. Inisiatif mencintaberasal dari Tuhan. Inilah cinta yang menjangkau semua ciptaan, cinta yang menjumpai Manusia dalam segala keberadaan hidupnya, cinta yang rela terluka, cinta yang mencakupdimensi universal dan personal manusia. Ritus Em So menggugah kesadaran manusia akankehadiran Tuhan, tidak hanya dalam keheningan doa, melainkan juga dalam tarian dan music tifa dan hidup sehari-hari.

Sebagi sebuah tradisi, ritus Em So dalam perkembangannya, mengalami 
perubahan.Menurut Tonny Potes, praktik Em so mengalami perubahan yaitu sejak tahun 1998.Pada masa inilah, Em Soberangsur-angsur memudar. Dalam artian bahwa tidak seperti tahun-tahun sebelumnya. Hal ini dikarenakan, praktek Em so dilakukan oleh orang dari marga-marga tertentu yang mempunyai kewenangan untuk melantunkan nyanyian dan menabuh tifa namun upaya mewariskannya kepada generasi seterusnya tidak dilakukan secara ketat. Sampai sejauh ini belum banyak generasi muda Asmat yang punya kerinduan untuk belajar nyanyian dan menabuh tifa serta berupaya untuk mengembangkannya.

Em so dalam Ritus Tow Pok 'Mb sarat makna dalam kaitan dengan masyarakat Asmat memahami hubungan mereka dengan Tuhan yang di sembah, sesama dan alam dimana mereka hidup. Namun kenyataannya, Em so belum mendapat perhatian, baik dari pihak gereja maupun pemerintah, selain untuk melestarikannya tapi yang paling penting adalah menggali makna-makna terdalam yang terbungkus rapi di dalamnya untuk lebih memahami kerakteristik masyarakat Asmat secara utuh. Di sisi lain, adanya perkembangan dan perubahan masyarakat lokal yang cenderung menganggap ritus budaya dan semua yang mengarah pada kesenian tradisional sebagai sesuatu yang ketinggalan zaman dibanding dengan seni dan budaya populer dewasa ini menjadi ancaman tersendiri. Jika hal ini tidak di tanggapi secara serius maka tentu akan berdampak pada punahnya Em so sebagai warisan budaya local

\section{Em so sebagai local genius suku Asmat}

Geertz berpendapat bahwa kebudayaan adalah"pola dari pengertianpengertianatau maknayangterjalinsecaramenyeluruh dalamsimbol-simbolyang ditransmisikansecara historis,suatusistem mengenai konsepsi-konsepsi yang diwariskan dalam bentuk-bentuk simbolik dengan cara tersebut manusia berkomunikasi, melestarikan dan mengembangkan pengetahuan dan sikap mereka terhadap kehidupan ${ }^{9}$. Hal ini menunjukan bahwa bagi Geertz kebudayaan merupakan hasilkarya manusia yang dapat mengembangkan sikap terhadap kehidupan dan diwariskandari satu generasi ke generasi berikutnya melalui proses komunikasidanbelajar agar generasi yang diwariskan memiliki karakter yang tangguh dalam menjalankan kehidupan. 
Banyak hal yang dapat membentuk seseorang atau sekelompok orang memiliki karakter yang tangguh dalam hidupnya. Salah satu dari sekian banyak hal yang terjadi, nampak dalam Tow Pok 'Mbu yang merupakan warisan budaya lokal dan menjadi salah satu kekhasan hasil budaya suku Asmat. Ritus ini menandakan sebuah pencerminan karakteristikatas local genius yang membedakannya dengan budaya dari suku-suku lain di Indonesia termasuk Papua.Aktivitas musik melalui em so, umumnya dipandang sebagai sesuatu yang berkaitan dengan diri manusia dan kebudayaannya. Di balik fenomena perilaku bermusik, ada sejumlah alasan mengapa manusia bermusik dan apa maknanya bagi mereka?.

Em so dikenal memiliki cara pengekspresian yang kuat, terkesan spontan, dan mempunyai ritme yang khas. Karakteristik em so yang relatif berbeda dengan kultur nyanyian di sekitarnya memicu penilaian tersendiri bagi masyarakat yang berada di luar kultur nyanyian tersebut. Kesan inilah yang membawa pada sebuah pemahaman bahwa bahwa Em So bukan nyanyian biasa dan itulah gambaran ekspresi menyanyi orang Asmat.

Em so sebagai local genius tergambar melalui latar belakang gaya nyanyian dan pendalaman interpretasi terhadap karakter $E m$ so sebagai nyanyian jiwa (the soul song) yang mengungkapkan puji-pujian kepada Sang Bapa melalui Fumeripits. Fenomena nyanyian yang berakar dari suasana batin, maka spirit Em so tampil lebih menonjol, mempengaruhi bentuk dan gaya nyanyian itu sendiri. Lingkungan alam Asmat yang ber-rawa-rawa, banyak ditumbuhi pohon sagu, pohon kayu besi dan masyarakat berjuang melangsungkan aktivitas hidup di atas papan turut memberi kontribusi bagi dunia ide pengalaman batin yang terefleksikan dalam spirit Em So secara komprehensif.

Bagi masyarakat tradisional, alam dan segala materinya baik makhluk hidup, benda mati, dan segala energy yang ada adalah semesta dunia religi mereka. Dalam konstruksi batin yang demikian, maka kerapkali terdapat kepercayaan bahwa sesuatu yang terdapat di alam adalah perpanjangan tangan Dewa-dewa, Roh leluhur, atau Sang MahaKuasa. Sehingga segala bentuk aktivitas religi masyarakat tradisional begitu dekat dengan lingkungan alamnya ${ }^{10}$. Sebagai local genius, Em soadalah bagian dari aktivitas religi masyarakat Asmat memahami hubungan 
dengan Tuhan, sesama dan alam. Kehadiran em so dalam ritus tow pok mbu mencerminkan luapan emosi sebagai bentuk penghayatan untuk kehidupan komunitas yang lebih baik.

\section{Hubungan Musik dan Ritual}

Berbicara mengenai musik, Alan P Merriam menyebutnya sebagai suatu lambang dari hal-hal yang berkaitan dengan ide-ide maupun perilaku suatu masyarakat ${ }^{11}$.Hal ini berarti musik adalah salah satu dari kebudayaan yang diciptakan oleh manusia, bukan sekedar memenuhi kebutuhannya akan keindahan melainkan menjadi sarana ekspresi diri dari berbagai pengalaman dan harapan tentang arti hidup yang sesungguhnya.Sedangkan ritualmerupakan tata cara dalam upacara atau suatu perbuatan keramatyang dilakukanolehsekelompok masyarakat yang ditandai dengan adanya berbagai macam unsur dan komponen, yaitu adanya waktu, tempat-tempat dimana upacara dilakukan, alat-alat dalam upacara, serta orang-orang yang menjalankan upacara ${ }^{12}$. Pada dasarnya ritual adalah rangkaian kata, tindakan sesorang atau sekelompok orang dengan menggunakan benda-benda, peralatan dan perlengkapan tertentu, ditempat tertentu dan memakai pakaian tertentu pula.

Hubungan musik dan ritual nampak dalam aktivitas hidup masyarakat pendukungnya karena music memberikan peranan yang sangat penting dalam sejarah manusia. Musik memiliki pengaruh yang sangat kuat bagi emosi manusia. Musik dapat menjadi alat untuk merangsang emosi pendengarnya, memberikan inspirasi tersendiri bagi masayarakat pendukungnya.Menurut Merriam, sistim musik selalu mempunyai struktur, namun struktur tersebut harus dipandang sebagai produk tingkah laku. Sementara, tingkah laku itu muncul karena didasari oleh suatu konsep tertentu. Hasilnya,tanpa konsep musik, tingkah laku tidak akan ada, dan tanpa tingkah laku, suara musik tidak akan dihasilkan.Sebaliknya, produk tingkah laku (musik) dapat memberi masukan atau sebagai referensi terhadap konsep-konsep tersebut sesuai dengan yang dirasakan masyarakatnya terhadap nilai musik mereka sendiri ${ }^{13}$. Sesungguhnya peristiwa music terjadi dari fenomena yang siklis ketika musik telah dilahirkan, dijaga dan dikembangkan secara terus-menerus. 
Musik sebagai material struktur bunyi tidak begitu saja kelahirannya secara utuh ditentukan oleh konvensi masyarakatnya, sebab materinya sendiri berupa struktur musik, juga ikut mempengaruhi masyarakat dalam proses mengonstruksi atau memaknai seperti apa keindahan musik yang dibangun atau diterima oleh mereka. Jika materinya mengalami perubahan, maka materi yang berubah itu ikut memberi peran dalam proses seseorang atau masyarakat dalam memaknaikembali musiknya.Bruner menyebutnya bahwa ekspresi dan pengalaman budaya memiliki hubungan dialektis yaitu ketika pengalaman manusia menstruktur ekspresi maka ekspresi juga dapat menstruktur pengalaman ${ }^{14}$. Dari kedua hubungan 'pengalaman dan ekspresi'itu, pemaknaan indigenous dapat ditemukan, sebab ekspresi merupakan artikulasi, formulasi, dan representasi dari pengalaman mereka.

Hubungan musik dan ritual dapat juga dilihat secara jelas melalui fungsi musik dalam kehidupan manusia ${ }^{15}$ antara lain :

1. Fungsi pengungkapan emosional

Disini musik berfungsi sebagai suatu media bagi seseorang untuk mengungkapkan perasaan atau emosinya. Dengan kata lain si pemain dapat mengungkapkan perasaan atau emosinya nelalui musik.

2. Fungsi komunikasi.

Musik memiliki fungsi komunikasi berarti bahwa sebuah musik yang berlaku di suatu daerah kebudayaan mengandung isyarat-isyarat tersendiri yang hanya diketahui oleh masyarakat pendukung kebudayaan tersebut. Hal ini dapat dilihat dari teks atau pun melodi musik tersebut.

3. Fungsi perlambangan

Musik memiliki fungsi dalam melambangkan suatu hal. Hal ini dapat dilihat dari aspek-aspek musik tersebut, misalmya tempo sebuah musik. Jika tempo sebuah musik lambat, maka kebanyakan teksnya menceritakan hal-hal yang menyedihkan. Sehingga musik itu melambangkan akan kesedihan.

4. Fungsi reaksi jasmani

Jika sebuah musik dimainkan, musik itu dapat merangsang sel-sel saraf manusia sehingga menyebabkan tubuh kita bergerak mengikuti irama musik tersebut. Jika musiknya cepat maka gerakan kita cepat, demikian juga sebaliknya.

5. Fungsi yang berkaitan dengan norma sosial

Musik berfungsi sebagai media pengajaran akan norma-norma atau peraturan-peraturan. Penyampaian kebanyakan melalui teks-teks nyanyian yang berisi aturan-aturan.

6. Fungsi pengesahan lembaga sosial.

Fungsi musik disini berarti bahwa sebuah musik memiliki peranan yang sangat penting dalam suatu upacara . Musik merupakan salah satu unsur yang penting dan menjadi bagian dalam upacara, bukan hanya sebagai pengiring. 
7. Fungsi kesinambungan budaya.

Fungsi ini hampir sama dengan fungsi yang berkaitan dengan norma sosial.

Dalam hal ini musik berisi tentang ajaran-ajaran untuk meneruskan sebuah sistem dalam kebudayaan terhadap generasi selanjutnya.

8. Fungsi pengintegrasian Masyarakat

Musik memiliki fungsi dalam pengintegrasian masyarakat. Suatu musik jika dimainkan secara bersama-sama maka tanpa disadari musik tersebut menimbulkan rasa kebersamaan diantara pemain atau penikmat musik itu.

Melalui fungsi musik diatas, dapat di tegaskan bahwa hubungan musik dan ritual sangatlah erat dalam perjalanan hidup suatu komunitas. Setiap ritual pasti ada musiknya yang memberikan gambaran tentang kebutuhan terpenting penganutnya tentang berbagai hal yang menjadi harapan dan cita-cita bersama. Dalam ritual tow pok mbu, musik tifa sebagai musik tradisional masyarakat suku Asmat menjadi bagian yang penting dalam menentukan keberhasilan sebuah ritus.Em (tifa) dalam ritus Tow Pok Mbu selain sebagai pengiring tarian tapi juga pengiring nyanyian. Sebagai pengiring nyanyian, Em (tifa) ditabuh sedemikian rupa sesuai gaya nyanyiannya. Semakin kencang tifa ditabuh atau dibunyikan dengan ritme yang menjadi ciri khas musik tifa, maka semakin lantang suara nyanyiannya.

\section{Gambaran tentang Ritual Tow Pok Mbu}

Ritual merupakan pengulangan perilaku [sifatnya yang berulang-ulang], normatif, simbol dan fungsional. Sering juga disamakan dengan ekspresi keagamaan/religius. Ritus merupakan kegiatan formal, sanksi institusional, dan ritual keagamaan, sedangkan adat istiadat merupakan ritual informal dengan pengalaman masyarakat yang sekuler. ${ }^{16}$ Durkheim menggambarkan bagaimana ritual-ritual dalam budaya masyarakat primitif menghasilkan kohesi/kepaduan dalam komunitas dan menciptakanA Moral $\operatorname{Order}^{17}$.Dia mengidentifikasi dua perbedaan antara ritus dan keyakinan dalam agama.Ritus keagamaan termasuk menolong individual bergerak/berpindah dari dunia yang profan/duniawi ke dunia yang sacral/kudus. Pergerakan ini meliputi "ritual attitude/sikap ritual" yang negatif dan positif. Ritual negatif adalah kegiatan secara fisik, melihat, dengan kata-kata dan aktivitas seksual dan mempersiapkan seseorang pada inisiasi ritus ke dalam pemujaan. Ritual positif, pada tangan yang lain merupakan dasar dari budaya/peradaban institusi keagamaan yang besar. Ritual positif yang utama 
berpusat pada sekeliling pelaksanaan Perjamuan Makan atau Perjamuan Kudus. Durkheim juga mengatakan representasi religius adalah representasi kolektif yang mengungkapkan realitas kolektif. Ritus-ritus yang ada di dalamnya adalah cara untuk bertindak yang hanya muncul di tengah-tengah kelompok saat berkumpul dan bertujuan untuk membangkitkan, mempertahankan atau membangun kembali berbagai kondisi mental kelompok itu. ${ }^{18}$

Kesucian sebagai nilai ultima suatu komunitas bukan hanya dipelihara dengan punishment atau pengucilan dan cap-cap sosial negatif, melainkan juga dengan ritus. Kesatuan yang dibangun atas dasar kepentingan kepentingan bersama akan yang suci ini melahirkan ritus sosial. Masyarakat menghidupi dirinya dengan bergerak dari dan ke the sacred. Perayaan-perayaan, festival, dan acara-acara budaya dalam masyarakat itu dapat disebut sebagai bentuk-bentuk ritus.

Ritus diadakan secara kolektif dan regular agar masyarakat disegarkan dan dikembalikan akan pengetahuan dan makna-makna kolektif. Ritus menjadi mediasi bagi anggota masyarakat untuk tetap berakar pada the sacred. Saraf-saraf kesadaran disentuhkan kembali pada yang keramat-biasanya, yang keramat lebih mudah diterima, tidak dipertanyakan, kalau sudah dijadikan mitos yang didalamnnya terdapat nilai-nilai dan makna kolektif yang disakralkan untuk merasakan dan mencecap sensasi keramatan sebelum kembali pada kehidupan sehari-hari. Dalam ritus dihadirkan kembali makna realitas dalam masyarakat (makna sosial). Dengan demikian, ritus berperan memperkokoh keberakaran (rootedness) rasa kolektivitas karena menggiring anggota masyarakat "meminum" dari sumber kekeramatan yang sama. Oleh karena itu, masyarakat melalui ritus mendapatkan legitimasi berkat bersentuhan kembali dengan makna-makna fundamental yang mengkontruksi masyarakat tersebut. Dalam ritus tersebut masyarakatmemperbarui kerangka epistemologis yang secara multidimensional menentukan dinamikanya. Ritus merupakan proses rekreasi masyarakat; masyarakat menciptakan dirinya kembali melalui ritus-ritus. ${ }^{19}$

Semua kebudayaan mempunyai beberapa bentuk yang terulang-ulang, tingkah laku yang tersimbolisasi yang diikat dengan bentuk-bentuk penjelasan tertentu sebagai cara mendasar untuk memahami makna atau tujuan hidup 
mereka. Tingkah laku simbolik yang berulang-ulang inilah yang disebut dengan ritual. Jelaslah, seperti yang dideskripsikan Arbuckle, ritual berfungsi untuk mengekspresikan makna di dalam konteks sosial tertentu melalui gerakan tubuh dan gesture secara simbolik yang berulang-ulang. Ritual terjadi dalam konteks sosial, yaitu manalaka ada ketegangan/konflik dalam relasi sosial dan upaya diambil baik untuk menyelesaikan atau menyembunyikan ketegangan tersebut. Dalam tradisi Barat misalnya, waktu orang menyelesaikan atau menyembunyikan ketegangan atau konflik di antara mereka, mereka saling berjabatan tangan, yang merupakan sebuah gerak tubuh yang secara lahiriah mengandung makna menyimbolkan damai batiniah yang dipulihkan. Elaine Ramshaw menjelaskan hal ini dengan menjelaskan bahwa ritual menjawab kebutuhan untuk tetap mengikat komunitas. $^{20}$

Menurut Turner, masyarakat kolektif akan bergerak antara tertata (order) dengan tidak tertata (disorder), masyarakat dalam keadaan berayun-ayun dalam sejarahnya. Melalui liminalitas, masyarakkat hirarki digantikan oleh masyarakat setara yang disbut komunitas. Dinamika tertata/tidak semacam ini selalu ada dalam masyarakat, bahkan yang liminal itupun akan menginstitusionalisasi diri. ${ }^{21}$

Dengan demikian, ritus bukan sekedar dinamika perngulangan yang berulang-ulang, melainkan gerakan yang terus mengulang dengan menyerap pembaharuan-pembaharuan ${ }^{22}$.Salah satu tokoh penelitinVictor Turner $^{23}$ telah meneliti tentang proses ritual pada masyarakat $\mathrm{N}$ dem budi Afrika. Menurut Turner,ritus-ritus yang diadakan oleh suatu masyarakat merupakan penampakan dari keyakinan religius.Ritus-ritus yang dilakukan itu mendorong orang-orang untuk mentaati tatanan sosial tertentu. Ritus memberikan motivasi dan nilai-nilai pada tingkat yang paling dalam ${ }^{24}$. Melalui ritus, penganutnya menemukan eksistensi sebagai hasil penghayatan mendalam yang secara langsung mengikat mereka dalam satu komunitas dengan sejumlah nilai-nilai hidup didalamnya.Jika menghubungkannya dengan kehidupan Suku Asmat, ritus yang dimaksudkan oleh Turner nampak dalam kehadiran bermacam pesta. Salah satunya yaitu Tow Pok $M b u$ sebagai sarana aktualisasi diri dalam tindakan religiusnya memahami realita hidup dalam hubungannya dengan Tuhan yang disembah, sesama dan alam.

Pals mengatakan bahwa simbol merupakan gambaran yang sakral dan 
yang profane. Selain itu simbol berfungsi sebagai mediator manusia untuk berhubungan dengan yang sakral. Sebab manusia tidak bisa mendekati yang sakral secara langsung, karena yang sakral itu adalah transenden sedangkan manusia adalah mahkluk temporal yang terikat didalam dunianya ${ }^{25}$. Orang Asmat, mengenal yang sakral melalui simbol. Simbol yang dimaksudkan disini secara khusus adalah sagu dan ulat sagu. Dalam masyarakat tertentu, sagu dan ulat sagu termasuk bahan makanan yang biasa-biasa saja namun tidak bagi masyarakat suku Asmat, sagu dan ulat sagu adalah sesuatu yang sakral. Pohon sagu sebagai simbol mama yang melahirkan, ialah yang disayangi, di jaga dan dipelihara, mama yang memiliki kekuatan untuk berjuang ditengah - tengah terpaan angin badai. Mama yang menyediakan ulat sagu bagi anggota keluarganya sebagai sumber protein dan lemak yang lezat dan bernilai tinggi. Menurut Thomas Baphci, ulat sagu selain sebagai sumber protein dan lemak yang lezat dan bernilai tinggi namun sesungguhnya dalam pandangan orang Asmat, ulat sagu memiliki makna tersendiri yaitu sebagai simbol kasih. Kasih kepada semuanya. Dalam pesta ini, ulat sagu akan di makan oleh semua anggota persekutuan dan juga akan dibagikan kepada marga-marga yang ada dalam komunitasnya. Ulat sagu mempersatukan mereka dalam sebuah ikatan kasih yang tidak tercerai-berai dan hidup berdamai satu dengan yang lain.Ritus ini dilakukan jika ada kesepakatan dari tokoh-tokoh adat sehubungan dengan peristiwaperistiwa yang terjadi dan nantinya akan terjadi dalam komunitasnya. Selain untuk menjaga keutuhan hidup komunitas yang saling mengasihi dan hidup berdamai satu dengan yang lain (Jika ada pertikaian antar marga dan terjadinya musibah yang berkepanjangan), juga untuk rencana panen sagu, pembangunan dan peresmian $\mathrm{Jew}^{26}$.

Thomas Bapchi katakan bahwa Proses ritus Tow Pok Mbu dimulai ketika beberapa orang melihat ulat sagu secara langsung di hutan (kurang lebih 1 bulan, pohon sagu sudah di tebang untuk nantinya diambil ulat sagu) dan hasilnya akan disampaikan kepada tua-tua adat. Selanjutnya di tentukan kapan dilaksanakannya panen atau proses pengambilannya di hutan. Perjalanan ke hutan oleh sekelompok laki-laki disertai tua-tua adat dengan menggunakan "ci” (perahu) berarak-arakan menunju hutan tempat ulat sagu itu berada. Dengan menyiapkan 
Sakambot (piring dari pelepah sagu), ulat sagu diisi dan dibungkus dengan daun sagu. Kemudian dalam perjalanan kembali kekampung, rombongan dari hutan disambut oleh perempuan-perempuan dan tetua adat lainnya yang tidak ikut dalam pengambilan ulat sagu di hutan dengan berbagai ekspresi antara lain ada menangis, menggulingkan badannya ke lumpur dan memanah busurnya ke atas sebagai ungkapan sukacita karena panen ulat sagu berhasil dan berjalan dengan baik. Selanjutnya dibawa ulat sagu dan perlengkapan lainnya termasuk para perempuan dan anak-anak membawa sumbangan bahan makan dan minuman ke Jew dihadapan "wair" (tetua adat) sebagai ungkapan pentingnya sebuah kebersamaan hidup sekaligus menghormati tradisi leluhur . Acara Tow Pok Mbu kemudian dilanjutkan dengan cara pemukulan em (tifa) sebagai tanda dimulainya pesta oleh tetua adat. Selama berlangsungnya pesta, ada tiga hal penting yang dilakukan yaitu :

- Menyanyi

Nyanyian Tifa (Em so) di lantukan oleh Paduan yang berperan sekaligus sebagai Penabuh Tifa (sambil menabuh tifa, kelompok penabuh tifa melantunkan Em so). Kelompok ini terdiri dari 5-8 orang yaitu para tuaadat. Nyanyian yang dibawakan adalah nyanyian bernada syukur dan nyanyian yang mengkisahkan tentang alam sekaligus kisah hidup mereka yang didalamnya terkandung nilai hidup yang harus ditaati oleh penganutnya.

- Menari

Kelompok penari adalah peserta pesta yang terdiri dari laki-laki dan perempuan dewasa namun tidak menutup kemungkinan bagi mereka yang mau terlibat secara langsung termasuk anak-anak. Tarian "goyang paha" untuk laki-laki sebagai simbol kemenangan dalam perang sedangkan perempuan melakukan tarian "goyang pinggul: sebagai simbol kesetiaan dalam melakukan tanggung jawabnya. Kelompok penari menari mengikuti irama tifa dan lantunan nyanyian dari paduan penabuh Em so.

- Makan bersama

Makan bersama dilakukan setelah menyanyi dan menari. Makanan yang dimakan adalah sagu, ulat sagu dan bahan-bahan lainnya seperti pisang, 
ubi-ubian, ikan yang di bawa oleh anggota persekutuan. Makan bersama adalah peristiwa yang penting dalam ritus ini karena melalui makan bersama merupakan simbol dari ikatan persekutuan anggota komunitas, simbol untuk hidup berbagi sekaligus hidup berdamai satu dengan yang lain.

Pesta berlangsung selamanya 2-3 hari di jew (disesuaikan dengan ketersediaan ulat sagu yang di panen dan bahan makanan yang dibawa). Tow Pok Mbu dinyatakan tutup dengan cara pemukulan tifa oleh oleh Tetua adat. Pesta selesai dan masyarakat kembali beraktivitas seperti biasa (memancing ikan, berburu, mengambil sagu di hutan dan mungkin ada yang mengadakan perjalanan untuk urusan tertentu ke luar kampung).

\section{Penggunaan Em sodan Maknanya dalam Ritus Tow Pok Mbu}

Nyanyian musik tifa (em so) sebagai salah satu ciri khas orang Papua termasuk suku Asmat lahir, hidup dan berkembang didalam komunitasnya. Em so merupakan warisan para Tetua adat kepada generasinya yang mengkisahkan tentang kekaguman terhadap ciptaan Tuhan, rasa syukur dan memohon penjagaan serta hidup saling berdamai dan berbagi. Em so sebagai sarana ungkapan perasaan dan puji-pujian mereka kepada Sang Ilahi melalui Fumeripits (Leluhur) serta menegaskan, pentingnya hidup bersama sebagai satu persekutuan. Em so dinyanyikan secaraspontan dan termasuk dalam tradisi lisanya itu melodi dan teksnya tidak tertulis.Teks atau syair diciptakan sendiri oleh penyanyi (hanya orang-orang tertentu misalnya tokoh adat dan mereka yang mempunyai kewenangan untuk hal itu). Em So tidak sebatas dilihat dari aspek bentuknya sebagai gaya nyanyian, melainkan berupaya pula mengungkap perilaku atau cara kerjamenyanyiyangmampu menumbuhkan dan menghidupkannya. Pengungkapan atassuatu gaya nyanyian ibarat sebuah pintu masuk untuk mengetahui isi ruangan (nilai-nilai) yang hanya ada dalam dunia ide, konsep dan keyakinan.

Menurut Daniel Dampits, Em So dinyanyikan pada saat puncak acara Tow Pok Mbu yaitu didalam jew sambil yang lainnya menari (Em so sebagai pengiring tarian). Em so dan $N d i$ (tarian) punya keterkaitan yang erat karena Em So merupakan spirit bagi setiap gerak tarian. Em so memiliki rytem yang 
tetap dan berulang-ulang serta bersifa tresitatif (seperti berbicara). Ketika Em so dinyanyikan, bukan hanya menimbulkan reaksi terhadap gerakan tubuh untuk menari namun bagi orang tertentu, bisa juga menimbulkan reaksi yang lain yaitu dengan cara menangis (orang yang menangis biasanya mengingat sanak saudaranya yang telah meninggal dunia). Hal ini sejalan dengan pandapat Purba tentang nyanyian Etnis:"Fungsi utama nyanyian adalah untuk mengekspresikan rasa,dan sekaligus sebagai suatu aktivitas dari berbagai jenis komunikasi manusia. Nyanyian sangat dibutuhkan oleh masyarakatnya. Selanjutnya isi nyanyian tersebut lebih bersifat komunikasi sosial dibandingkan komunikasi individuallebih bersifat normatif dibandingkan menjelaskan fakta ${ }^{27}$.

Atas dasar itu, Em So dalam ritus Tow Pok Mbu suku Asmat diasumsikan sebagai ekspresi gaya nyanyian yang dapat menerangkan pengalaman terdalam komunitasnya, dan juga dapat mengantarkan imajinasi atau persepsi masyarakat pemiliknya ke arah pengalaman tertentu. Em So sebagai salah satu bentuk ekspresi telah dimaknai secara komunal sebagai perwuju dan pengalaman budaya suku Asmat yang mengarah pada kesimpulan teoritik bahwa suatu ekspresi yang ditampilkan merupakan pencerminan atas pengulangan-pengulangan suatu pengalaman. Suatu gayanyanyian yang terpola dan dipertahankan, merefleksikan adanya konsep yang telah terumuskan dengan mapan dan mampu mengarahkan pelakunya dalam menafsirkan dan mempraktikkan gaya menyanyi secara terpola juga.

Em so menjelaskan sesuatu yang ada dalam hidup mereka dan itu menjadi warisan nilai hidup komunitas suku Asmat. Dampits katakan bahwa Kisah hidup mereka, di ceriterakan melalui nyanyian. Berikut ini adalah nyanyian "Juwur Berpit”. Nyanyian ini di karang oleh Daniel Dampits.

Juwur berpit, akapaitu doropeyi

Awer berpit aitu doropeyi

Tiju duruwi ufu des ari panama juwabut ea reabi Tiwi cemeni pajicamuni. Tiwi cemeni paji camuni.

Tamuna doropei jiya aiyi... Ha...

Nyanyian ini menceriterakan bahwa ada seorang laki-laki Asmat pergi berburu dan mendapat dua ekor babi. Iamembawa pulang satu ekor ke rumah untuk di makan oleh keluargannya (anak dan isterinya) dan satunya, dibawa ke 
Jew sebagai persembahan. Nyanyian Juwur berpit adalah salah satu Em so dalam ritusTow pok ' $m b u$, mau menjelaskan tentang aktivitas yang dilakukan oleh seorang laki-laki Asmat yaitu berburu.Ia seorang cekatan sehingga dapat membunuh dua ekor babi. Menarik bahwa selain dapat memberi makan bagi keluarganya, seekor babi yang lain, ia bawa ke Jew sebagai persembahan. Ia mengingat kepada komunitasnya. Ia mau hidup berbagi. Makna terdalam dari nyanyian ini yang menjadi nilai hidup masyarakat Asmat adalah mengucap syukur karena penjagaan Sang Bapa melalui Fummeripits yang terjadi dalam hidup mereka. Secara khusus mencari makan bagi keluarga dan sikap hidup berbagi untuk kepentingan bersama.

\section{Penutup}

Suku Asmat merupakan salah satu suku terbesar di tanah Papua yang memiliki berbagai macam ritus budaya unik. Kehidupan ritual yang sangat kompleks menjadi sebuah hal yang menarik untuk selalu di pelajari setiap waktu. Selain ukiran kayu yang sudah mendunia, Asmat terkenal juga melalui berbagai upacara (ritual) adat. Misalnya, ritual Tow Pok Mbu (Pesta Ulat Sagu). Ritus ini dilakukan sebab Orang Asmat, mengenal yang sakral melalui simbol. Simbol yang dimaksudkan disini secara khusus adalah sagu dan ulat sagu. Dalam masyarakat tertentu, sagu dan ulat sagu termasuk bahan makanan yang biasa-biasa saja namun tidak bagi masyarakat Asmat, sagu dan ulat sagu adalah sesuatu yang sakral.

Ritual adat ini menjadi sesuatu yang khas karena ritual ini hidup dan sekaligus menghidupkan mereka dalam merefleksikan eksistensi dalam komunitasnya. Dalam ritual ini, musik tifa ( $E m s o$ ) mempunyai peranan tersendiri yaitu sebagai pengiring nyanyian (So) dan juga pengiring tarian (Ndi). Tifa akan di tabuh sedemikian rupa untuk mengiringi nyanyian dan tarian "goyang paha" untuk laki-laki sebagai simbol kemenangan dalam perang dan tarian "goyang pinggul untuk perempuan sebagai simbol kesetiaan dalam melakukan tanggung jawabnya. Kelompok penari menari mengikuti irama tifa dan lantunan nyanyian dari paduan penabuh Em so dan itu menjadi gaya khas sesuai identitas cultur suku Asmat. Dalam Ritus ini, em so memberikan nuansa tersendiri yang berkaitan 
dengan kedalaman makna sebagai bentuk penghayatan, bagaimana kehidupan dibangun dan terus berlangsung dalam hubungannya dengan Tuhan, sesama dan alam.

\section{Endnote :}

\footnotetext{
${ }^{1}$ John Blacking, How Musical is Man? Seattle and London: University of WashingtonPress, 1974. h 27

${ }^{2}$ Warna-warni Emosi dalam Musik" dalam www.ruangpsikologi.com/warna-warnaemosi-dalammusik/diakses 21 Juli 2016
}

${ }^{3}$ B. Kuhlen Verlag, Asmat, mencerap kehidupan dalam seni Jerman : Druckhaus Cramer, 2002.h. 238 Meskipun kanibalisme adalah tradisi masa lalu, tradisi tersebut telah menjadi stereotype yang dilekatkan pada suku Asmat sehingga orang selalu membayangkan Suku Asmat adalah suku pembunuh (jahat) sangat tradisional, dan ditakuti. Stereotipe ini sangatlah merugikan Suku Asmat, terutama dalam membangun relasi dengan irang lain di luar suku tersebut.

${ }^{4}$ Meskipun kanibalisme adalah tradisi masa lalu, tradisi tersebut telah menjadi stereotype yang dilekatkan pada suku Asmat sehingga orang selalu membayangkan Suku Asmat adalah suku pembunuh (jahat) sangat tradisional, dan ditakuti. Stereotipe ini sangatlah merugikan Suku Asmat, terutama dalam membangun relasi dengan irang lain di luar suku tersebut.

${ }^{5}$ Ernst Cassirer, Manusia dan Kebudayaan, PT. Gramedia Jakarta, thn 1987, h. 36

${ }^{6} \mathrm{Bdk}$ "Perempuan dan pohon sagu menurut masyarakat Napan Nabire "Oleh: Tisbed Stella Rarawi (Ibuselalumenyiapkan sarapanatau makananbagiseisikeluarganya.Karena itu dapatdikatakanbahwa ibu selalu memberikan kepada anak-anak dan suaminya kehidupan dalam bentuk makanan dan motivasi untuk hidup dan berkaryadalam pelukkan kasihsayangnya. Demikian jugapohon sagu, sebagai sumber kehidupan bagi Bagi masyarakat Napan Nabire, selalu menyediakan yang terbaik untuk pemenuhan kebutuhan komunalnya)

${ }^{7}$ Bdk. Tarian Kebalai dalam budaya Rote oleh Mesakh Djhata (Ritualitas dan Ekspresi Religius kebalai dilakukan sebagai tanda ucapan syukur dan sukacita. Ritual ini ditujukan kepada Lamatuak(Tuhan tertinggi) agar bisa memberikan berkat. Lamatuak tidak menghukum manusia, melainkan memberikan berkat berupa hujan yang berlimpah sehingga tanaman bisa tumbuh dengan baik dan sebagainya.

${ }^{8}$ Fumeripts adalah Perantara antara keberadaan mereka dengan Sang Bapa (Pencipta). Selain sebagai Perantara, Fumeripits juga sebagai Penggerak hidup yang memungkinkan mereka dapat melakukan aktivitas hidup setiap hari sedangkanSang Bapa adalah Pencipta.Dialah yang Maha Kuasa, yang menciptakan langit dan bumi dengan segala isinya.Dia adalah yang Ilahi dan tidak dapat dijangkau namun kehadirannya dapat di rasakan melalui karyaNya dalam alam semesta.

${ }^{9}$ Geertz,C. TafsirKebudayaan (RefleksiBudaya). Kanisius:Yogyakarta, 1992. h.16

${ }^{10}$ Mercia Eliade, Mitos tentang Gerak Kembali Yang Abadi atau Kosmos dalam Sejarah, Ikon Teralitera; cet. 1, 2002. h 27

${ }^{11}$ Alan P. Merriam, The Anthropology of Music Chicago North: Western UniversityPress,1964, h.42

${ }^{12}$ Alan P. Merriam, The Anthropology of Music (Chicago North: Western UniversityPress,1964),33.Liha tpula Alan P. Merriam, "Meninjau Kembali Disiplin Etnomusikologi"dalamR.Supanggah,ed.,Etnomusikologi Yogyakarta:Yayasan Bentang Budaya, 1995, h.84-85.

${ }^{13}$ EdwardM. Bruner dan Victor Turner, ed,The Anthropology of Experience Urbana and Chicago:University of Illinois Press, 1986. Hlm5-6.

${ }^{14}$ Alan P. Merriam, The Anthropology of Music Chicago North: Western University Press, 1964. Hlm 180-216

${ }^{15}$ Rodney J. Hunter, Dictionary of Pastoral Care and Counseling, Nashville: Abingdon Press, 19, h. $1088-1089$

16 Rodney J. Hunter, Dictionary of Pastoral Care, ...h. 1088-1089.

${ }^{17}$ Rodney J. Hunter, Dictionary of Pastoral Care, .... h 1088-1089. 


\footnotetext{
${ }^{18}$ Anthony Giddens, Daniel Bel dan Michel Forse (ed), Sosiologi Sejarah dan Berbagai Pemikirannya, (Yogyakarta: Kreasi Wacana, 2004), hlm. 50.

${ }^{19}$ Sebagai ilustrasi dapat dijelaskan demikian, Di Indonesia kita memiliki ritus lima tahunan yaitu Pemilihan Umum. Bagi masyarakat Indonesia, demokrasi dapat disebut sebagai nilai puncak (ungkapan hiperbolisnya "pesta demokrasi"). Solidaritas pengetahuan dan kesadaran masyarakat semakin menemukan kesatuan pada masa-masa menjelang pemilu.

${ }^{20}$ Elaine Ramshaw, Ritual And Pastoral Care, Philadelphia : Fortress Press, 1987, h. 29-30.

${ }^{21}$ Pembacaan yang lebih luas dan leluasa dapat mengantar kita melihat sub kultur semacam hippies, punk, rasta dan lain-lain sebagai bentuk antidote atas yang rasional, yang dominan-normal

${ }^{22}$ Muji Sutrisno dan Hendar Putranto, Teor-teori Kebudayaan, Yogyakarta : Kanisius, 2004. h.100

${ }^{23}$ Victor Turner lahir di Glaslow Skotlandia tahun 1920 dan meninggal tahun 1983. Ia adalah seorang ahli antropologi sosial. Ia mempelajari fenomena-fenomena religious suatu masyarakat.

${ }^{24}$ VictorTurner,TheAnthropologyofExperience (UrbanaandChicago:University), h. 42

${ }^{25}$ Daliel L. Pals, Dekonstruksi Kebenaran, (Yogyakarta : IRCiSoD,2003). h. 243

${ }^{26}$ Jew adalah sebuah konstruksi bangunan fisik yang mutlak ada dalam kehidupan komunitas. Jew bukan semata-mata sebuah persyaratan didalam memelihara kehidupan komunal akan tetapi lebih dari itu, jew merupakan pusat lingkaran konsentris, tempat "keramat" bagi komunitas suku asmat dalam memelihara struktur sosial bagi anggota komunitasnya, sehingga masing-masing anggota, tidak ada seorang individu yang mampu menjalani kehidupan seorang diri tanpa dukungan dari pihak lain. Jew adalah sebuah banguan tradisional (bangunan adat) dan didalam bangunan tersebut, pesta-pesta adat diselenggarakan, norma-norma kehidupan di sepakati bersama.

${ }^{27}$ Mauli Purba dalam artikelnya, Empat Komponen Kebudayaan Musikal Yang Perlu Dipahami

Dalam Rangka Pengembangan Musik paduan Suara Etnis, h.3,
}

\section{DAFTAR PUSTAKA}

Alan P. Merriam, 1964.The Anthropologyof Music (Chicago North: Western UniversityPress.

Blacking John, 1974.How Musicalis Man? (Seattle andLondon: University of Washington Press.

Bruner Edward M. dan Turner Victor, ed, 1986. The Anthropology of Experience. Urbana and Chicago: University of Illinois Press

Cassirer Ernst,1987. Manusia dan kebudayaan, Jakarta: PT. Gramedia.

Eliade Mircea, 2002. Mitos tentang gerak kembali yang abadi atau kosmos dalam sejarah, (Ikon Teralitera; cet. 1).

Geertz,C. 1992. TafsirKebudayaan (RefleksiBudaya), Yogyakarta: Kanisius.

Koentjaraningrat,1985.Beberapa Pokok Antropologi Sosial,Jakarta:Dian Rakyat.

Pals Daniel L., 2003.Dekonstruksi Kebenaran, Yogyakarta : IRCiSoD.

Ram shaw Elaine, 1987. Ritual And Pastoral Care, Philadelphia : Fortress Press.

SutrisnoMuji dan Putranto Hendar, 2004. Teori-teori Kebudayaan, Yogyakarta : Kanisius.

TurnerVictor,1986. The Anthropology of Experience.Urbanaand Chicago: Universy

VerlagB. Kuhlen, 2002. Asmat, Mencerap Kehidupan dalam Seni. Jerman : Druckhaus Cramer.

Artikel:

Mauli Purba; Empat Komponen Kebudayaan Musikal Yang Perlu Dipahami Dalam Rangka Pengembangan Musik paduan Suara Etnis. 